\title{
Phylogenetic analysis of nucleoprotein gene of Rabies virus in Malaysia from 2015 to 2018
}

\author{
Leow, B.L. ${ }^{1 *}$, Khoo, C.K. ${ }^{1}$, Syamsiah Aini, S. ${ }^{1}$, Roslina, H. ${ }^{1}$, Faizah Hanim, M.S. ${ }^{1}$ \\ ${ }^{1}$ Veterinary Research Institute, 59, Jalan Sultan Azlan Shah, 31400 Ipoh, Perak, Malaysia \\ *Corresponding author: leowbl@hotmail.com, leow@dvs.gov.my
}

\section{ARTICLE HISTORY}

Received: 14 December 2020

Revised: 4 March 2021

Accepted: 4 March 2021

Published: 30 April 2021

\begin{abstract}
Rabies is a fatal zoonotic disease caused by rabies virus (RABV) and remains a public health problem in Malaysia. Malaysia was declared rabies-free in 2012, however rabies outbreaks occurred at few states in Peninsular Malaysia three years later; and for the first time, in Sarawak (East Malaysia) in 2017 which has caused more than 20 human deaths. This study describes the phylogenetic analysis of the complete nucleoprotein $(N)$ gene of RABV from animal samples in Malaysia from year 2015 to 2018. The $N$ gene of 17 RABVs from Perlis, Kedah and Sarawak were amplified and sequenced. The nucleotide and deduced amino acid similarities of $N$ gene analysis indicated that there is high similarity among the local RABVs. Phylogenetic analysis of the $N$ gene revealed that all Malaysia RABVs belonged to the Asian clade. Among these, RABVs from Peninsular Malaysia were clustered together with RABVs from Thailand, Vietnam and other Southeast Asia countries except Indonesia. However, RABVs from Sarawak were grouped together with Indonesian strains from Kalimantan. Our study provides baseline genetic information of the potential origins of the circulating RABVs in Malaysia. This crucial information helped the authority in policies making and strategies to be taken in outbreak control. Continuous surveillance program to monitor the disease trend, strict border control, vaccination of dog and cat population and public awareness are important steps to control the spread of the RABV.
\end{abstract}

Keywords: Rabies virus; $N$ gene; Sarawak; Malaysia.

\section{INTRODUCTION}

Rabies, a fatal encephalitis disease, is caused by rabies virus (RABV) and is transmitted by the bite of rabid animal (Zhang et al., 2006). RABV belongs to the genus Lyssavirus in the family Rhabdoviridae (Bourhy et al., 1993, 2008; Dibia et al., 2015). The virus is a single-stranded, negative sense RNA virus with genome of approximately $12 \mathrm{~kb}$ that encodes for nucleoprotein $(N)$, phosphoprotein $(P)$, matrix protein $(M)$, glycoprotein $(G)$ and RNA-dependent RNA polymerase or large protein (L) (Zhang et al., 2006; Susetya et al., 2008; Dibia et al., 2015). Nucleoprotein plays an important role in inducing immunity especially against infection with heterologous Lyssaviruses (Bourhy et al., 1993). $N$ gene is highly conserved and therefore allows the genotyping of Lyssavirus based on nucleotide sequences (Bourhy et al., 1993).

Although all mammals can be infected by RABV, only few species of animals can transmit RABV to humans. Among them are several canid, feline and chiropteran species (Susetya et al., 2008) with more than 99\% human cases are caused by dog-mediated rabies (Bourhy et al., 2008). Rabies is also an important fatal zoonotic disease in many countries.
Fifty nine thousand human deaths annually around the world have been estimated to be due to dog-mediated rabies (WHO, 2018). The majority of deaths have occurred in Asia (59.6\%) and Africa (36.4\%) (WHO, 2018).

In Malaysia, rabies is a public health problem especially along the Malaysia and Thailand border. Dog is the primary reservoir of rabies infection in the country (Ganesan \& Sinniah, 1993). The success of the National Rabies Control Programme implemented in 1952 led Malaysia to declared as rabies-free country in 1954 (Ganesan \& Sinniah, 1993; Loke et al., 1998). However, sporadic rabies cases were still reported in Perlis, Kedah and Kelantan where these states share a common border with rabies endemic area in Thailand (Loke et al., 1998). The establishment of $50-80 \mathrm{~km}$ "immune belt" program in 1955 covering Perlis, Kedah, Kelantan and northern Perak, bordering Thailand and strict regulation of dog importation has successfully prevented the transmission of rabies from the north (Ganesan \& Sinniah, 1993). The success can be seen by only 1.3 cases per year were reported from 1955 to 1986, where most cases occurred at the border area and only 6 cases reported in other states among these years (Loke et al., 1998). Malaysia was again declared as rabies- 
free in July 2013 with the last case occurred in 1999 (OIE, 2013). However, three years after the declaration, rabies outbreaks reoccurred in Perlis, Kedah and Pulau Pinang (Navanithakumar et al., 2019). In 2017, rabies was reported for the first time in Sarawak, East Malaysia, causing 28 human deaths (Kpkesihatan.com, 2020). Until today, rabies remains a public health threat in our country.

The $N$ gene sequence data of RABVs is now widely used in the rabies molecular epidemiological studies as well as the origination, genetic diversity, distribution and the transmission pattern of the disease (Kissi et al., 1995; Zhang et al., 2006; Bourhy et al., 2008; Susetya et al., 2008; Dibia et al., 2015). For better management and control of rabies outbreak, sequencing data also enables various downstream molecular applications such as laboratory diagnosis and vaccine development. However, to date, there is no report on the complete $N$ gene nucleotide sequence of the RABV detected in Malaysia. Therefore, this study is to genetically characterize and phylogenetically analyze the complete $N$ gene of the RABVs detected in several states in Malaysia from 2015 to 2018 .

\section{MATERIALS AND METHODS}

\section{Samples}

Brain samples $(n=17)$ in this study were from various animals in different states in Malaysia that were received at Veterinary Research Institute (VRI), Ipoh for rabies diagnosis. These samples were collected from 2015 to 2018 either for diagnostic purpose or from surveillance activities. All samples were subjected to direct fluorescent antibody (DFA) test (OIE, 2018) prior to molecular detection. Rabies cases detected in Kedah and Pulau Pinang in 2015, and in Perak in 2017 are not included in this study due to the deterioration or insufficient sample for molecular detection.

Primers and Reverse transcription polymerase chain reaction (RT-PCR)

Samples that were positive for rabies by DFA test were subjected to RT-PCR. The viral RNA was extracted from the brain sample by phenol chloroform method using TRIzol LS Reagent (Invitrogen, USA) followed the manufacturer's instruction. Subsequently, RT-PCR was carried out using SuperScript III One-Step RT-PCR System with Platinum Taq (Invitrogen, USA). The primer sets used in this study were shown in Table 1 . The amplification was performed in T100 Thermal Cycler (Bio-Rad, USA). The reaction mix was then subjected to 1 cycle of reverse transcription at $48^{\circ} \mathrm{C}$ for $30 \mathrm{~min}$ and $94^{\circ} \mathrm{C}$ for $5 \mathrm{~min}$ for initial denaturation; 10 cycles of amplification at $94^{\circ} \mathrm{C}$ for $1 \mathrm{~min}, 37^{\circ} \mathrm{C}$ for $1 \mathrm{~min}$ and $68^{\circ} \mathrm{C}$ for 3 min; 20 cycles of amplification at $94^{\circ} \mathrm{C}$ for $1 \mathrm{~min}, 52^{\circ} \mathrm{C}$ for $1 \mathrm{~min}$ and $68^{\circ} \mathrm{C}$ for $3 \mathrm{~min}$ and the final extension was carried out at $68^{\circ} \mathrm{C}$ for $10 \mathrm{~min}$ (M. Chris, personal communication, November 4,2015 ). Primer set NF (forward): ACGCTTAACAACAAAAYCA DAGAAG and NR (reverse): GGRTTGACGAARATCTTGCTCAT designed by Feng et al. (2019) was also used in the study. This primer set can amplify approximately 1,536 bp which covers the entire $N$ gene of the RABV. In brief, the RT was carried out at $48^{\circ} \mathrm{C}$ for $30 \mathrm{~min}$. The reaction mix was then subjected to $94^{\circ} \mathrm{C}$ for 5 min for initial denaturation, followed by 40 cycles of denaturation at $94^{\circ} \mathrm{C}$ for $1 \mathrm{~min}$, annealing at $52^{\circ} \mathrm{C}$ for $1 \mathrm{~min}$ and extension at $68^{\circ} \mathrm{C}$ for $2 \mathrm{~min}$ with a final extension for $10 \mathrm{~min}$ at $68^{\circ} \mathrm{C}$. The amplicons were then analyzed by electrophoresis on $1.0 \%$ agarose gel stained with SYBR Safe DNA gel stain (Invitrogen, USA).
Gene sequencing, nucleotide/amino acid similarity analysis and phylogenetic analysis

The amplicons were cut from the gel and sent for Sanger sequencing (Apical Scientifics (M) Sdn Bhd). Primers used for DNA sequencing are corresponding to those used in the RT-PCR amplification. Nucleotide sequences were assembled using SeqMan Pro software (DNAStar Lasergene, USA). BioEdit Sequence Alignment Editor version 7.1.9 (Hall, 1999) was used in the alignment and comparison of the $N$ gene nucleotide sequences of the 17 local samples and other published sequences (Table 2). Similarities of nucleotide and deduced amino acid of the $N$ gene among the local samples were analyzed. A phylogenetic tree was constructed by NeighborJoining statistical method with model number of differences and setting bootstrap 1,000 replicates using MEGA version 6.06 (Tamura et al., 2013). The genetic relationship of the $N$ gene between the local samples and other respective strain in the world were examined through the phylogram.

\section{RESULTS}

Seventeen brain samples from 14 dogs and 3 cats collected from different area in several states which include Perlis, Kedah and Sarawak from 2015 to 2018 were used in the study (Table 3). All 17 samples were successfully amplified with $N$ gene specific primers. Nucleotide sequence of $1,353 \mathrm{bp}$ was used in the sequence comparison and phylogenetic analysis. The $N$ gene sequences obtained in this study have been submitted to GenBank under the accession numbers listed in Table 3. Sequences comparison revealed that 88.3 to $100 \%$ nucleotide similarity and 97.5 to $100 \%$ deduced amino acid similarity was detected among the Malaysia RABVs (Table 4). Among these, the nucleotide and deduced amino acid similarity of Kedah and Perlis RABVs was 99.1 to $100 \%$ and 99.3 to $100 \%$, respectively. On the other hand, nucleotide and deduced amino acid similarity of 99.8 to $100 \%$ and 99.7 to $100 \%$, respectively, was observed for the Sarawak RABVs.

The Malaysia RABVs were then compared with other rabies strains in the world. A total of 48 worldwide RABVs $N$ gene sequences retrieved from GenBank database were used in the sequence alignment and phylogenetic analysis. Phylogenetic analysis showed that all 17 Malaysia RABVs belongs to Asian clade (Figure 1). All seven RABVs that were detected in Perlis and Kedah were grouped in the Asian II lineage, whereas the ten RABVs collected from Sarawak were clustered in Asian I lineage. The Peninsular Malaysia RABVs

Table 1. Primer sets used in the amplification of complete $N$ gene (Bourhy et al., 1993)

\begin{tabular}{llcc}
\hline Name & Sequences 5' $-3^{\prime}$ & $\begin{array}{c}\text { Position in } \\
\text { rabies virus } \\
\text { PV strain }\end{array}$ & $\begin{array}{c}\text { Size of } \\
\text { amplicon } \\
(\mathrm{bp})\end{array}$ \\
\hline Rabies-N7 & ATG TAA CAC CTC TAC AAT G & $55-73$ & 1,531 \\
Rabies-N8 & AGT TTC TTC AGC CAT CTC & $1,585-1,568$ & \\
Rabies-N7 & ATG TAA CAC CTC TAC AAT G & $55-73$ & 591 \\
Rabies-N14 & TTG TGA GTA GTC ATT A & $645-630$ & \\
Rabies-N5 & GAA GGC AAT TGG GCT C & $419-434$ & 612 \\
Rabies-N2 & CCC ATA TAG CAT CCT AC & $1,030-1,013$ & \\
Rabies-N17 & TTC TTC CAC AAG AAC TTT G & $848-866$ & 738 \\
Rabies-N8 & AGT TTC TTC AGC CAT CTC & $1,585-1,568$ & \\
Rabies-N1 & TTTGAGACAGCCCCTTTTG & $587-605$ & 999 \\
Rabies-N8 & AGT TTC TTC AGC CAT CTC & $1,585-1,568$ & \\
\hline
\end{tabular}


Table 2. Reference RABV strains retrieved from GenBank database

\begin{tabular}{|c|c|c|c|c|c|c|}
\hline $\begin{array}{l}\text { Lyssavirus } \\
\text { genotype }\end{array}$ & Country & $\begin{array}{l}\text { Identification } \\
\text { number/strain }\end{array}$ & Species & Year & $\begin{array}{c}\text { Accession } \\
\text { number }\end{array}$ & Reference \\
\hline 1 & Afghanistan & 04027AFG & Dog & 1996 & EU086162.1 & Bourhy et al., 2008 \\
\hline 1 & Saudi Arabia & 8706ARS & Fox & 1987 & EU086163.1 & Bourhy et al., 2008 \\
\hline 1 & Myanmar & 9909BIR & Dog & 1999 & EU086164.1 & Bourhy et al., 2008 \\
\hline 1 & Myanmar & 9915BIR & Dog & 1999 & EU086166.1 & Bourhy et al., 2008 \\
\hline 1 & Cambodia & $9914 C B G$ & Dog & 1997 & EU086170.1 & Bourhy et al., 2008 \\
\hline 1 & Cambodia & 02006CBG & Dog & 1998 & EU086172.1 & Bourhy et al., 2008 \\
\hline 1 & China & $9811 \mathrm{CHI}$ & Dog & 1998 & EU086173.1 & Bourhy et al., 2008 \\
\hline 1 & China & 05009CHI & Dog & 2005 & EU086190.1 & Bourhy et al., 2008 \\
\hline 1 & India & 9702INDI & Human & 1997 & EU086191.1 & Bourhy et al., 2008 \\
\hline 1 & Indonesia & 03003INDO & Dog & 2003 & EU086192.1 & Bourhy et al., 2008 \\
\hline 1 & Laos & 9910LAO & Dog & 1999 & EU086193.1 & Bourhy et al., 2008 \\
\hline 1 & Nepal & 9901NEP & Dog & 1998 & EU086196.1 & Bourhy et al., 2008 \\
\hline 1 & Nepal & 9902NEP & Goat & 1998 & EU086197.1 & Bourhy et al., 2008 \\
\hline 1 & Philippines & $94273 \mathrm{PHI}$ & Dog & 1994 & EU086201.1 & Bourhy et al., 2008 \\
\hline 1 & Philippines & 03006PHI & Human & 2000 & EU086203.1 & Bourhy et al., 2008 \\
\hline 1 & Thailand & 8743THA & Human & 1983 & EU086207.1 & Bourhy et al., 2008 \\
\hline 1 & Thailand & 8738THA & Human & 1983 & EU086208.1 & Bourhy et al., 2008 \\
\hline 1 & Vietnam & 01016VNM & Dog & 2001 & EU086209.1 & Bourhy et al., 2008 \\
\hline 1 & Vietnam & 01017VNM & Dog & 2001 & EU086210.1 & Bourhy et al., 2008 \\
\hline 1 & Guinea & 9024GUI & Dog & 1990 & U22641.1 & Bourhy et al., 1995 \\
\hline 1 & South Africa & 1500AFS & Yellow Mongoose & 1987 & U22628.1 & Bourhy et al., 1995 \\
\hline 1 & Sri Lanka & 1294 & Dog & 1986 & AY138549.1 & Nanayakkara et al., 2003 \\
\hline 1 & Iran & 8681 IRA & Dog & 1986 & U22482.1 & Kissi et al., 1995 \\
\hline 1 & Poland & $8618 \mathrm{POL}$ & Raccoon Dog & 1985 & U22840.1 & Kissi et al., 1995 \\
\hline 1 & China, Fujian & FJ003 & Dog & 2008 & FJ561728.1 & Feng et al., 2016 \\
\hline 1 & China, Fujian & FJ008 & Dog & 2008 & FJ866835.1 & Feng et al., 2016 \\
\hline 1 & Inner Mongolia & CNM1104D & Dog & 2011 & KC252634.1 & Feng et al., 2016 \\
\hline 1 & China, Shanxi & SXDTD13 & Dog & 2013 & KT894584.1 & Feng et al., 2016 \\
\hline 1 & China, Guizhou & A103 & Dog & 2005 & DQ666290.1 & Feng et al., 2016 \\
\hline 1 & South Korea & KRC5-04 & Dog & 2004 & AY730597.1 & Park et al., 2005 \\
\hline 1 & China & HuNDN16 & Dog & - & DQ515993.1 & GenBank \\
\hline 1 & Mongolia & MGL-2 & Cattle & 2005 & AB570995.1 & Boldbaatar et al., 2010 \\
\hline 1 & Mongolia & MGL-22 & Dog & 2007 & AB571004.1 & Boldbaatar et al., 2010 \\
\hline 1 & Bangladesh & BDR7 & Cattle & 2010 & AB699219.1 & Jamil et al., 2012 \\
\hline 1 & Indonesia, Bali & BL659-09 & Dog & 2009 & JX462623.1 & Dibia et al., 2015 \\
\hline 1 & Pakistan & Pk 23 & Cattle & 2010 & HE802675.1 & GenBank \\
\hline 1 & Pakistan & Pk 24 & Cattle & 2007 & HE802676.1 & GenBank \\
\hline 1 & Bhutan & Btn115 & Cattle & 2010 & AB910532.1 & Jamil et al., 2012 \\
\hline 1 & China & CQWSD01 & Dog & 2005 & КT221095.1 & GenBank \\
\hline 1 & India & IAP-R91 & Buffalo & 2002 & KX434489.1 & GenBank \\
\hline 1 & Indonesia, Kalimantan & KL00-18 & Dog & 2000 & АВ154221.1 & Susetya et al., 2008 \\
\hline 1 & Indonesia, Kalimantan & KL97-03 & Dog & 1997 & AB154223.1 & Susetya et al., 2008 \\
\hline 1 & China & FJDRV & Dog & 2008 & JN609295.1 & GenBank \\
\hline 1 & Malaysia, Serian & RB03 & Human & 2017 & MF620996.1 & GenBank \\
\hline 1 & Laos & Lao11 & Dog & 2012 & AB981671.1 & Ahmed et al., 2015 \\
\hline 1 & Thailand & D23 & Dog & - & AY218996.1 & Hemachudha et al., 2003 \\
\hline $\begin{array}{l}\text { Vaccine } \\
\text { strain }\end{array}$ & - & AVO1 & - & - & X13357.1 & Poch et al., 1988 \\
\hline 5 & France & 03002FRA & Bat & 2003 & EU293109.1 & Dolmes et al., 2008 \\
\hline
\end{tabular}



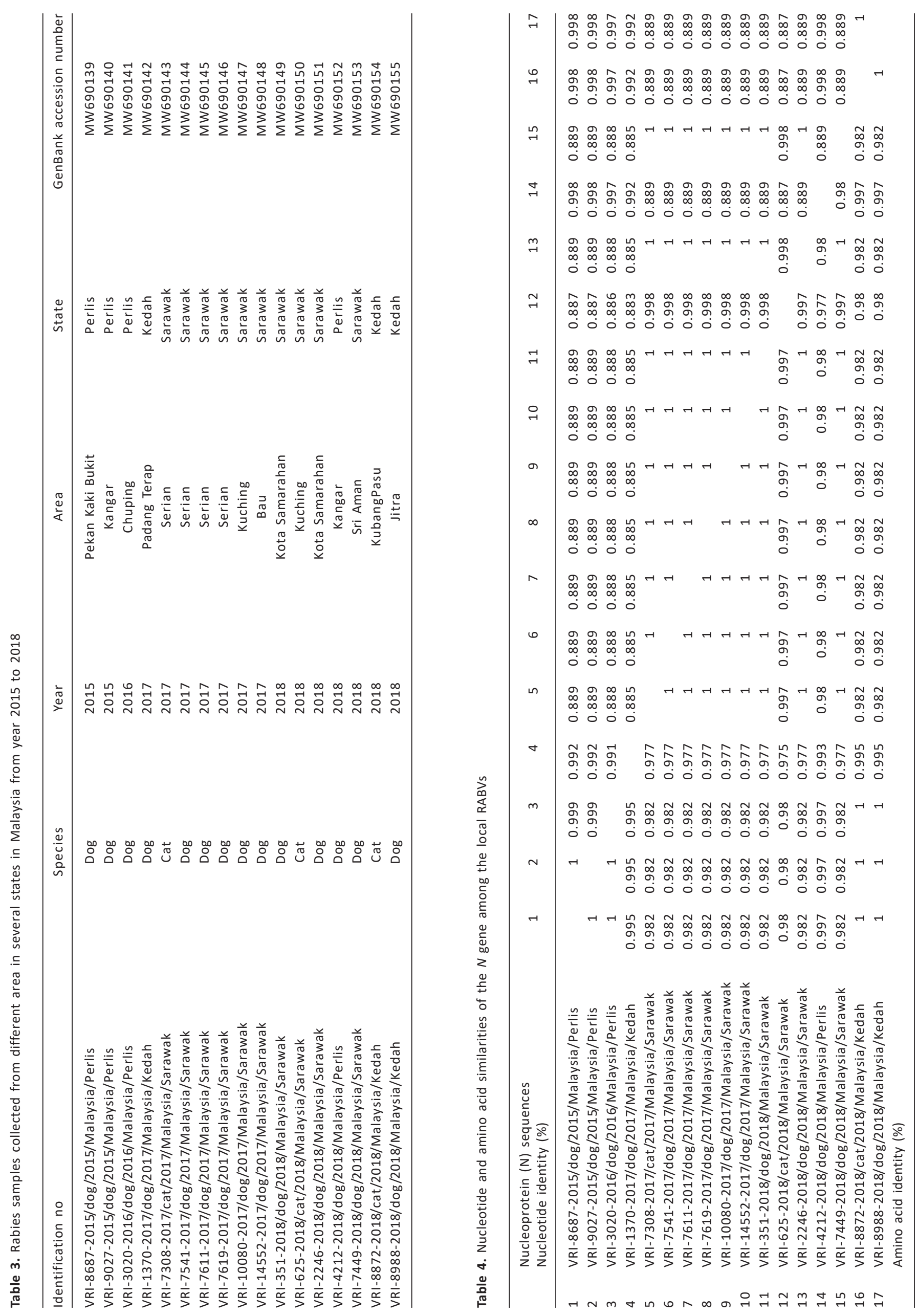


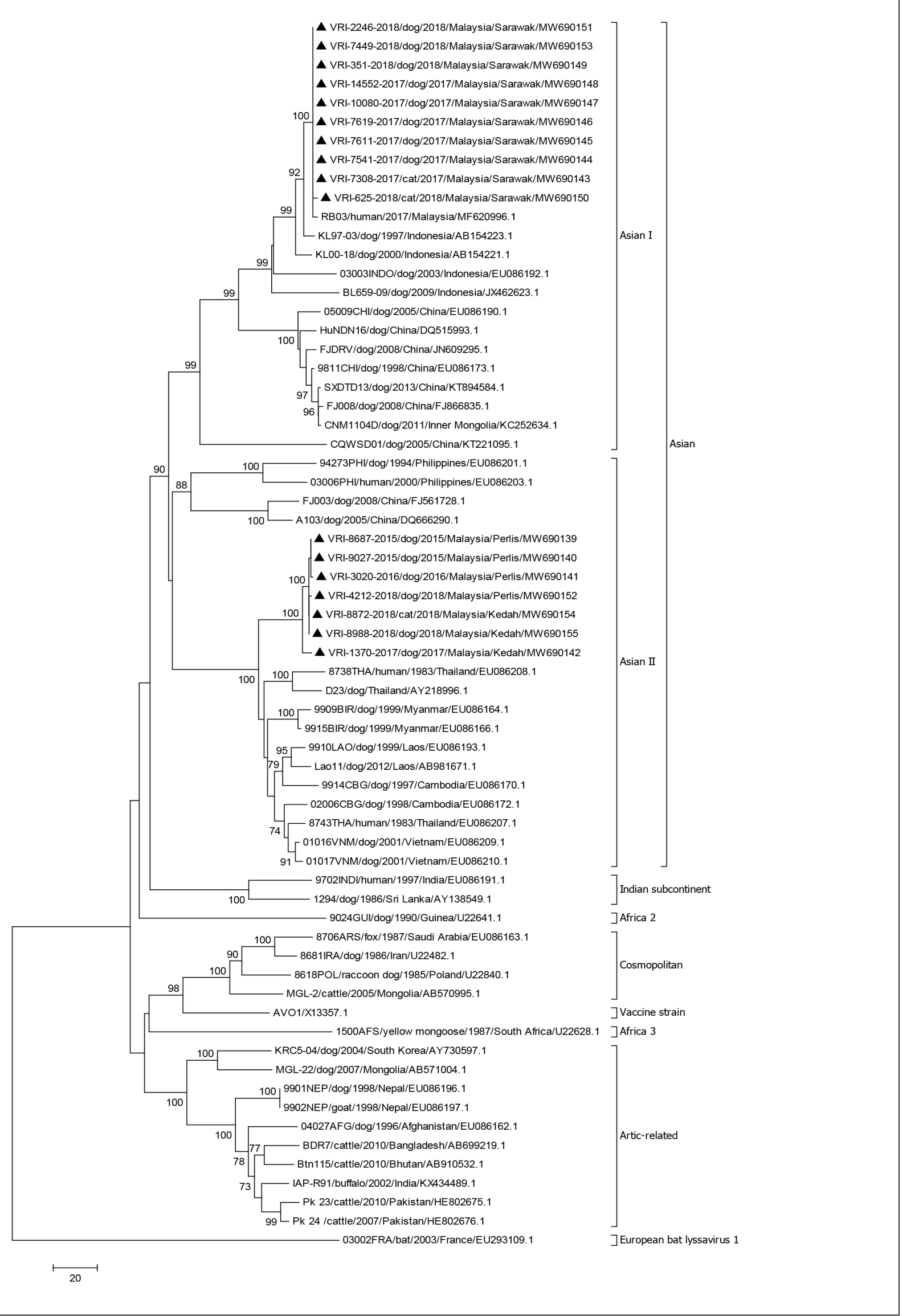

Figure 1. Phylogenetic tree of 17 local RABVs and 48 reference rabies strains based on complete $N$ gene of RABV. Tree was constructed using MEGA version 6.06 by Neighbour-Joining statistical method with model number of differences and setting bootstrap 1,000 replicates. European bat Lyssavirus 1 was used as outgroup. Nodes with bootstrap values more than $70 \%$ are shown. The black triangles ( $\boldsymbol{\Delta}$ ) represent the Malaysian RABVs. The local strain name is suffixed by VRI disease investigation number / species / year detected / country / state /GenBank accession number. 
formed a distinct cluster in the phylogenetic analysis despite the difference in the years and location where the virus was detected. Based on the phylogenetic analysis, these viruses belonged to the same group of Asian II lineage RABVs from Thailand, Vietnam and other Southeast Asia countries excluding Indonesia. Conversely, the RABVs detected in Sarawak formed a unique cluster not only among themselves but also with human RABV detected in Serian, Sarawak. The RABVs from Sarawak is grouped together and closely related to RABVs isolated in Kalimantan (Indonesia), China and InnerMongolia that belongs to Asian I lineage.

\section{DISCUSSION}

RABV can be classified into six groups, the Africa 2, Africa 3, Artic-related, Asian, Cosmopolitan and Indian subcontinent clades based on the phylogenetic analysis of the $N$ gene (Bourhy et al., 2008, Puyati et al, 2016). In this study, all Malaysia RABVs were grouped in Asian clade, indicating close relationship with the RABVs circulating in Asia. This is in agreement with Kissi et al. (1995) and Puyati et al. (2016) that RABV found in Malaysia, Thailand, Cambodia, Laos, Myanmar, Indonesia, Philippines and Vietnam are clustered in the Asia clade.

The findings of this study showed that there are two different genetic groups of RABVs circulating in Malaysia. RABVs detected in Perlis and Kedah were grouped in Asian II lineage, which is associated with the virus from Thailand, Myanmar, Laos, Cambodia and Vietnam (Feng et al., 2019), indicates potential sharing of a common ancestor. From the geographical point of view, the Peninsular Malaysia is connected to Thailand, and further up with Myanmar, Cambodia, Laos, Vietnam and other countries. Thus, it is not surprising that the RABVs detected in Kedah and Perlis are closely related to the RABVs that were isolated in these countries. In addition, from 2015 to 2018, there were no rabies cases reported in other states in the Peninsular indicating that rabies is confined to the northern states of Peninsular Malaysia that bordering Thailand, highlighting the importance of the 'immune belt'. The immune belt serves as a buffer zone to allow the permanent rabies control measures to be continuously implemented (Navanithakumar et al., 2019). In the immune belt area, compulsory dog licensing and vaccination program are carried out. Unlicensed and stray dogs will be put down humanely. Public education is conducted not only to the public but also school children, to deliver the knowledge and enhance rabies awareness among the community (Navanithakumar et al., 2019).

The same goes to the Sarawak state where the virus detected is highly similar to those in the Kalimantan (Indonesia). These findings are in accordance with reports by Bourhy et al. (2008) and Dibia et al. (2015) that RABV is grouped according to their geographical origin. Sarawak is four times larger than the northern region of Peninsular Malaysia (Perlis, Kedah, Pulau Pinang and Perak) in total land area, yet the RABV detected in these areas were distinct and confined to their respective geographical area. This observation was further evidenced whereby the RABVs detected in Malaysia grouped in their respective cluster despite different in the year and location within the same state.

Bamaiyi (2015) hypothesized that the outbreaks in Perlis and Kedah occurred in 2015 was transmitted from Thailand by land movement. The hypotheses can be further supported by the BLAST analysis of the $N$ nucleotide sequences of the two viruses (VRI-8687-2015 and VRI-9027-2015) detected in Perlis in 2015, and these two RABVs have the highest nucleotide similarities with rabies strains from Thailand at $96.66 \%$ and $96.58 \%$, respectively. Likewise, the rabies outbreak in Sarawak was believed to be spread from the neighboring region, Kalimantan, Indonesia. Rabies was identified in West Kalimantan in year 2005 and the virus is still circulating in the province though the province has been once declared as rabies-free in April 2014 (Antara Kalbar, 2018). According to Faizul et al. (2019), the Sarawak outbreak was caused by the interaction between the pets and strays dogs in Sarawak with the infected dogs from endemic area in Kalimantan. Due to the long border and geographical proximity between Sarawak and Kalimantan, it is difficult to prevent the dogs from crossing over the border and interacting with each other. Therefore, RABV can be easily introduced into Sarawak due to the porous border (Faizul et al., 2019). In addition, with the construction of Pan Borneo Highway, and more land opening up for oil palm plantation, the foreign workers may have brought the animals with them from West Kalimantan (Vickneshwaran, 2018). This is in agreement with Bourhy et al. (2008) and Dibia et al. (2015) that human-mediated animal movements can cause introduction and transmission of rabies that has been seen in some countries including United States and Indonesia.

Rabies cases have not been reported in Sabah and Sarawak up until 2017 where the first rabies case was reported in Serian, Sarawak (Navanithakumar et al., 2019). To date, rabies has spread to all divisions in Sarawak except Limbang. Limbang is free from rabies so far due to its geographical inaccessibility with the only road connection to outside the division is through Brunei (Suara Sarawak, 2020). Additionally, Brunei which is rabies-free (OIE, 2012) also serves as a buffer zone for Limbang. However, this may change with the completion construction of road linking Limbang to Marudi, Baram and Miri by-passing Brunei (Suara Sarawak, 2020). Mass vaccination of dogs in Sarawak including Limbang is also being carried out (Sarawak Government, 2019). Being aware of the risk, Sabah has taken initiative to vaccinate the dog inside $30 \mathrm{~km}$ of Sabah along the border of Sarawak and Kalimantan (Ahmed \& Ibrahim, 2019) and so far remained rabies-free.

Rabies cases in Malaysia are mainly associated with dogs, but there are also cases detected in cats as detected in this study. As mentioned by Bourhy et al. (2008) and Dibia et al. (2015), rabies are predominantly affecting dogs and spillover infection into non-reservoir hosts such as human, livestock, cats and wild animals can also happen. The RABVs detected in cats in this study are highly similar to those present in dogs with less than $1 \%$ difference of $N$ gene nucleotide and deduced amino acid similarity. Importantly, the cat RABV was clustered within the same clade with dog RABV according/in to their respective geographical origin. All these may indicate potential spillover of rabies infection from dog to cat. As cats often lick their paws and like to interact with human, thus, RABV can be transmitted to human by a rabid cat through biting or scratching (Ahmed \& Ibrahim, 2019). Although, there are only few cat-mediated rabies cases, the importance of spillover rabies infection into cats cannot be neglected.

To date, rabies has caused 28 human deaths in Sarawak. Though rabies is a fatal zoonotic disease, it can be preventable. Malaysia government has taken drastic measures to control the disease which involve culling the stray dogs (Bamaiyi, 2015) and mass vaccination of the animals including dogs and cats in the affected area. Strict border control should be implemented to restrict the free movement of animals and people across the border. Porous border will increase the risk of influx of RABV from neighboring countries. The 
maintenance of the existing immune belt at the border of Thailand and the new establishment of an immune belt along the Sarawak-West Kalimantan border is important to control and prevent the disease. Licensing of dogs, strict regulation on importation of dogs, public awareness, and the responsibility of the pet owner also plays an essential role in controlling the disease.

\section{CONCLUSION}

This study describes the molecular characterization of rabies in Malaysia based on the phylogenetic analysis of the complete $N$ gene sequences of RABV. This study indicates that Asian I and Asian II of RABVs are circulating in the country from 2015 to 2018 by analyzing the rabies positive samples from different geographical area from several states. The finding suggested that RABVs from the rabies endemic bordering countries might have been introduced to Malaysia and spread in the country. By determining the genetic characteristic and the origin of the circulating RABV, it helps the authority in policy making and strategies taken to control the disease.

\section{ACKNOWLEDGEMENTS}

The authors would like to thank the Director General of Veterinary Services Malaysia (DVS) for his kind permission to publish this scientific paper. Special thanks also to the Director of Veterinary Research Division, DVS and the Director of Veterinary Research Institute (VRI) for their support in this study. This study was financially supported by VRI Ipoh.

\section{Conflict of interest}

The author declares that they have no conflict of interests.

\section{REFERENCES}

Ahmed, K. \& Ibrahim, M.Y. (2019). The silent expansion of rabies in Borneo. Borneo Journal of Medical Sciences 13: 1-2. https://doi.org/10.51200/bjms.v0i0.1837

Antara Kalbar. (2018). Sebaran rabies yang menghantui kalbar. https://kalbar.antaranews.com/berita/361282/sebaranrabies-yang-menghantui-kalbar. Accessed 29 September 2020.

Bamaiyi, P.H. (2015). 2015 Outbreak of canine rabies in Malaysia: Review, analysis and perspectives. Journal of Veterinary Advances 5: 1181-1190. https://doi.org/10.5455/ jva.19691231040000

Bourhy, H., Kissi, B. \& Tordo, N. (1993). Molecular diversity of the Lyssavirus genus. Virology 194: 70-81. https://doi.org/ 10.1006/viro.1993.1236

Bourhy, H., Reynes, J., Dunham, E.J., Dacheux, L., Larrous, F., Huong, V.T.Q., Xu, G., Yan, J., Miranda, M.E.G. \& Holmes, E.C. (2008). The origin and phylogeography of dog rabies virus. Journal of General Virology 89: 2673-2681. https:// doi.org/10.1099/vir.0.2008/003913-0

Dibia, I.N., Sumiarto, B., Susetya, H., Putra, A.A.G., Scott-Orr, H. \& Mahardika, G.N. (2015). Phylogeography of the current rabies viruses in Indonesia. Journal of Veterinary Science 16: 459-466. https://doi.org/10.4142/jvs.2015.16.4.459

Faizul, F.M.Y., Syamsiah, A.A.S., Roslina, H., Norazura, A.H., Ahmad Fikri, A.Y., Syamsul, N.N. \& Faizah, H.M.S. (2019). Phylogenetic analysis of rabies viruses detected in Malaysia. Malaysian Journal of Veterinary Research 10: 3238.
Feng, Y., Liu, Y., Wang, Y., Gong, W., He, B., Guo, H., Tu, C. \& Thompson, L. (2019). Manual laboratory training on rabies, Ipoh, Malaysia, 7-11 October 2019. pp.1-43.

Ganesan, J. \& Sinniah, M. (1993). Occurrence of human rabies in Peninsular Malaysia. Medical Journal of Malaysia 48: 194199.

Hall, T.A. (1999). BioEdit: A user-friendly biological sequence alignment editor and analysis program for Window 95/ 98/NT. Nucleic Acids Symposium Series 41: 95-98.

Kissi, B., Tordo, N. \& Bourhy, H. (1995). Genetic polymorphism in the Rabies virus nucleoprotein gene. Virology 209: 526537. https://doi.org/10.1006/viro.1995.1285

Kpkesihatan.com (2020). Kenyataan Akhbar KPK 21 November 2020 - Situasi Terkini Rabies di Sarawak. https:// kpkesihatan.com/2020/11/21/kenyataan-akhbar-kpk-21november-2020-situasi-terkini-rabies-di-sarawak/. Accessed 14 December 2020.

Loke, Y.K., Murugesan, E., Suryati, A. \& Tan, M.H. (1998). An outbreak of rabies in dogs in the state of Terengganu 1955-1996. Medical Journal of Malaysia 53: 97-100.

Navanithakumar, B., Sohayati, A.R., Rohaiza, Y., Sarah, D.A., Mariani, H., Leonora, T.M. \& Dorothy, K.S. (2019). An overview of rabies outbreaks in Malaysia, ordinances and laws. Malaysian Journal of Veterinary Research 10: 148158.

OIE. (2012). World Animal Health Information Database (WAHIS Interface). https://www.oie.int/wahis_2/public/ wahid.php/Countryinformation/Countryreports. Accessed 30 September 2020.

OIE. (2013). Self-declaration by Malaysia on its rabies-free status https://www.oie.int/doc/ged/D13109.PDF. Accessed 30 September 2020.

OIE Terrestrial Manual. (2018). Chapter 3.1.17. Rabies (Infection with rabies virus and other Lyssaviruses). Paris: World Organization for Animal Health, pp. 578-612.

Puyati, B., Senayai, S., Chanachai, K. \& Panichabhongse, P. (2016). Epidemiological and genetic characteristics of rabies virus in Ubon Ratchathani province, Thailand, 20112014. Outbreak, Surveillance and Investigation Reports 9: 8-14.

Sarawak Government. (2019). Sarawak Government Collaborates With Counterparts In Indonesia, Brunei And Sabah To Contain Rabies Spread. https://www.sarawak. gov.my/web/home/news_view/119/13116. Accessed 29 September 2020.

Suara Sarawak. (2020). Jalan alternatif dalam pembinaan. https://suarasarawak.my/2020/06/16/jalan-alternatifdalam-pembinaan/. Accessed 29 September 2020.

Susetya, H., Sugiyama, M., Inagaki, A., Ito, N., Mudiarto, G. \& Minamoto, N. (2008). Molecular epidemiology of rabies in Indonesia. Virus Research 135: 144-149. https://doi.org/ 10.1016/j.virusres.2008.03.001

Tamura, K., Stecher, G., Peterson, D., Filipski, A. \& Kumar, S. (2013). MEGA6: Molecular Evolutionary Genetics Analysis version 6.0. Molecular Biology and Evolution 30: 2725-2729. https://doi.org/10.1093/molbev/mst197

Vickneshwaran, M. (2018). Rabies Malaysia. https://rabies alliance.org/resource/lessons-learned-malaysia. Accessed 11 June 2020.

WHO. (2018). WHO Expert Consultation on Rabies. Third Report WHO technical report series No 1012. Vol. 2018. Geneva: World Health Organization, pp. 183.

Zhang, Y.Z., Xiong, C.L., Zou, Y., Wang, D., Jiang, R., Xiao, Q., Hao, Z., Zhang, L., Yu, Y. \& Fu, Z.F. (2006). Molecular characterization of rabies virus isolates in China during 2004. Virus Research 121: 179-188. https://doi.org/10.1016/ j.virusres.2006.05.010 